Int. J. Morphol.,

35(1):251-258, 2017

\title{
Evaluation of the Effect of Platelet-Rich Plasma on Alveolar Wound Healing in Rats
}

\author{
Evaluación del Efecto del Plasma Rico en Plaquetas en la \\ Cicatrización de Heridas Alveolares en Ratas
}

Marcos Kazuo Yamamoto' ${ }^{1}$ Moacyr Domingos Novelli; Luciana Corrêa $^{2}$; Suzana Cantanhede M. de Sousa ${ }^{3}$ \& João Gualberto C. Luz ${ }^{1}$

YAMAMOTO, M. K. ; NOVELLI, M. D.; CORRÊA, L.; DE SOUSA, S. C. M. \& LUZ, J. G. C. Evaluation of the effect of plateletrich plasma on alveolar wound healing in rats. Int. J. Morphol., 35(1):251-258, 2017.

SUMMARY: Opinions about the clinical utility of platelet-rich plasma (PRP) vary, as a large number of experimental studies have questioned its efficacy. The purpose of this study was to evaluate the effects of PRP on experimental alveolar wound healing in rats. Fifty young adult male Wistar rats were divided in control and PRP groups and submitted to extraction of the right maxillary incisor. In the PRP group, blood was collected by cardiac puncture, and the socket was filled with a PRP gel. Animals were euthanized after 1, 3, 7, 14 and 30 days. Histological and histomorphometric analyses were performed at each experimental time point. Semiquantitative histological analysis showed that the PRP group exhibited significantly more collagen-matrix deposition and less bone-matrix formation in the socket than did the control group from 7 to 30 days. Histomorphometric analyses showed that the PRP group also exhibited lower bonetissue areas than the control group at $7(\mathrm{p}=0.0250)$ and 14 days $(\mathrm{p}<0.0001)$, but at 30 days, no significant difference between the groups was observed. In the present study, PRP did not enhance alveolar wound healing, and PRP-treated rats exhibited low rates of bone deposition during the intermediate phases of alveolar socket repair.

KEY WORDS: Tooth socket; Wound healing; Platelet-rich plasma; Animal experimentation.

\section{INTRODUCTION}

A number of clinical trials have reported effects, such as increased bone formation and maturation rates, of the use of autologous platelet-rich plasma (PRP) to enhance the wound healing process, mainly when applied with bone grafts of different origins (Wiltfang et al., 2003; Oyama et al., 2004; Marx, 2004; Steigmann \& Garg, 2005). However, opinions of the clinical utility of PRP vary (Sánchez et al., 2003; Gürbüzer et al., 2008) as a large number of experimental studies have questioned its efficacy (Gerard et al., 2006; Mooren et al., 2007; Plachokova et al., 2008; Oliveira Filho et al., 2010). On the other hand, the properties of PRP are promising, and further studies are warranted.

The effects of PRP on bone and soft-tissue healing have been related to an increased quantity of growth factors, such as platelet-derived growth factor (PDGF), transforming growth factor- $\beta$ (TGF- $\beta$ ), vascular endothelial growth factor (VEGF), epithelial growth factor (EGF), insulin growth factor-I (IGF-I) and basic fibroblast growth factor ( $\beta F G F)$, being delivered to the surgical area (Weibrich et al., 2002; Plachokova et al.). PDGF is believed to stimulate the proliferation of fibroblasts in the periodontal ligament and their migration into a clot, while TGF- $\beta$ may be important in the differentiation of fibroblasts into osteoblasts, inducing these osteoprogenitor cells in the residual periodontal ligament to contribute to bone regeneration following tooth extraction (Devlin \& Sloan, 2002). Thus, the effects of PRP that may be related to histological and histomorphometric evaluations are osteoblastic activity, bone matrix formation and trabeculae connectivity, as well as newly formed bone tissue.

The preservation of the alveolar socket following tooth extraction is essential prior to implant placement and minimizes the need for future augmentation procedures. The use of PRP and calcium sulfate may enhance bone healing after tooth extraction (Kutkut et al., 2012). PRP may also prevent periodontal defects after a lower third molar has been

${ }^{1}$ Department of Oral and Maxillofacial Surgery, School of Dentistry, University of São Paulo, São Paulo, Brazil.

${ }^{2}$ Department of General Pathology, School of Dentistry, University of São Paulo, São Paulo, Brazil.

${ }^{3}$ Department of Oral Pathology, School of Dentistry, University of São Paulo, São Paulo, Brazil. 
extracted (Sammartino et al., 2009). Other advantages of treatment with PRP include a reduction in intraoperative and postoperative bleeding, as well as greater stability of grafted tissue (Kutkut et al.). Moreover, a reduction in the severity of complications, such as alveolar osteitis, and an improvement in soft-tissue healing have been reported for PRP treatment following tooth extraction (Alissa et al., 2010).

The purpose of the present study was to evaluate the effects of PRP on experimental alveolar wound healing in rats using histological analysis.

\section{MATERIAL AND METHOD}

Experimental groups. Fifty adult male Wistar rats with a mean weight of $213.8 \mathrm{~g}$ were fed an ordinary rodent diet (Labina, Agribands Purina, São Paulo, Brazil) and kept under standard laboratory conditions. The animals were randomly divided into two groups: a control group $(n=25)$ of animals submitted to maxillary incisor extraction and a PRP group $(n=25)$ of animals submitted to maxillary incisor extraction followed by PRP insertion into the dental alveolus. This study was approved by the local Animal Experimentation Ethics Committee (protocol number CEEAICB 055/001).

Surgical procedure. General anesthesia was induced with $10 \mathrm{mg} / \mathrm{kg}$ of $2 \%$ xylazine hydrochloride (Rompum, Bayer, Porto Alegre, RS, Brazil) and $25 \mathrm{mg} / \mathrm{kg}$ of $10 \%$ ketamine hydrochloride (Dopalen, Vetbrands, Paulínia, SP, Brazil) intraperitoneally. After antisepsis, the gingival tissue surrounding the right maxillary incisor was detached, luxation was performed with a Hollenback instrument, and the incisor was extracted with forceps. In the PRP group, PRP was inserted into the alveolus immediately after dental extraction.

In the control group, the clot that had formed after the dental extraction was maintained. At the end, in all animals, the marginal gingiva was sutured with 5-0 nylon monofilament thread. All the animals were euthanized at 1 , $3,7,14$, and 30 days ( $\mathrm{n}=5$ at each time point) after dental extraction with a lethal dose of ketamine hydrochloride and xylazine hydrochloride intraperitoneally.

PRP preparation. PRP was obtained following this protocol: briefly, $2.5 \mathrm{ml}$ of blood was collected by cardiac puncture and placed into two 1.5-ml microcentrifuge tubes (Eppendorf AG, Hamburg, Germany), each containing of $60 \mathrm{ml}$ of $10 \%$ trisodium citrate solution (Unipharmus Pharmacy, São Paulo, Brazil), an anticoagulant. The tubes were centrifuged (model 5415c, Eppendorf AG, Hamburg, Germany) at a relative force of $82 \times \mathrm{g}(1000 \mathrm{rpm})$ for 5 minutes at room temperature. The blood was separated into red blood cells at the bottom of the tubes and plasma containing platelet concentrate in the upper portion; $0.25 \mathrm{ml}$ of plasma situated near the boundary of the red blood cells was removed from each tube. A total of $0.5 \mathrm{ml}$ of plasma containing platelet concentrate was obtained, to which $80 \mathrm{ml}$ of red blood cells collected from the uppermost portion of the tubes and $20 \mathrm{ml}$ of $10 \%$ calcium chloride were added. After 5 minutes, a soft gelatinous substance had formed. The autologous gel of each animal was applied immediately after its preparation. This process was performed by removing the existing clot from the alveolar socket by irrigation with saline solution. A syringe with a curved needle was then used to insert the platelet-rich gel. The PRP volume administered was the same for all animals.

The animals maintained their diet and continued to gain weight. All animals had good healing and there were no cases of infection. Immediately after euthanasia, maxillae were retrieved and fixed in $10 \%$ buffered formalin.

Histological and histomorphometric analyses. After decalcification in $20 \%$ formic acid, the incisor alveolus was cut into three portions to obtain transverse slices of the apical, middle and cervical thirds. Semi-serial, $7-\mu \mathrm{m}$-thick sections were obtained and stained with haematoxylin and eosin (H\&E). Histological and histomorphometric analyses were performed at each experimental time point, without making a distinction among the three thirds. The resulting data were analysed jointly to obtain a global score for each alveolus.

Semiquantitative histological analyses were performed by one pathologist who described the extension, in the visible area of the alveolus, of tissue elements directly involved in the bone repair process. This extension was graded for all experimental time points according to the following criteria: 0 , total absence of the tissue element; 1 , tissue element present in up to $25 \%$ of the alveolar area; 2 , tissue element present in $50 \%$ of the alveolus; 3 , tissue element present in $75 \%$ of the alveolus; and 4, tissue element present in more than $75 \%$ of the alveolus. The tissue elements that were analysed were necrosis, clot, inflammatory infiltration, oedema, collagen deposition, angiogenesis, bone matrix formation, and connectivity of bone trabeculae. The median score for each experimental time point and group was assigned to that time point and group.

Histomorphometric analysis was performed to quantify new bone formation in the alveolus at 7, 14, and 30 days. Digital histological images were obtained using an 
optical microscope (Leica DM2500, Leica Biosystems, Wetzlar, Germany) attached to a digital system consisting of a camera (Leica DFC 295, Leica Biosystems, Wetzlar, Germany) and morphometry software (LAS ${ }^{\circledR}$, Leica Biosystems, Wetzlar, Germany). All slices were exposed to the same microscope light intensity. To register the entire alveolus, two fields were digitized at a magnification of 50×, one for each alveolus extremity. At least two slices from each third of each alveolus were digitized. The bone tissue present in the alveolar space was quantified using the freehand tool of Image J software (National Institutes of Health, Bethesda, Maryland, USA). First, the border of the alveolar space was drawn, and the total area was obtained. Then, the newly formed bone tissue was surrounded using the same tool, and the bone-tissue area was calculated. The alveolar and bone-tissue areas obtained in the first field were summed with those obtained in the second field. Then, the bone-tissue area was divided by the total alveolar area and multiplied by 100 to obtain the percentage of bone-tissue formation in relation to the alveolar area. This procedure was performed for each histological slice. Only the cervical and middle thirds were analysed because it was not always possible to maintain the standardization in apical thirds because of anatomical variations. All procedures were performed in a blinded manner by one operator without knowledge of the group being analysed.

Statistical analysis. In semiquantitative analyses, histological scores are presented as medians and minimum and maximum values. Percentages of the bone-tissue area in the alveolus are given as means and standard deviations. The Mann-Whitney test was used to compare the control and PRP groups at each experimental time point. Friedman's test was adopted to compare the bone-tissue percentages obtained at the experimental time points in each group individually. The level of significance was set to $5 \%$.

\section{RESULTS}

Platelet concentrations ranged from $340 \%$ to $380 \%$ of that in peripheral blood with the protocol used.

Histological analysis. Table I shows the median score for each tissue element observed in the histological slices for each group and experimental time point. Necrosis was not observed in any group during the experiment. The main differences between the two groups were in the permanency of inflammatory infiltration at 14 days $(\mathrm{p}=0.008)$ and of clot remnants at 30 days $(\mathrm{p}=0.016)$ in the PRP group, and in less oedema at 3 days $(\mathrm{p}=0.027)$ compared with the control group. Another difference was that intense angiogenesis, characterized by the presence of large blood vessels in the middle of the clot, was observed at 7 days in the PRP group $(\mathrm{p}=0.013)$. The PRP group also exhibited high scores for the presence of connective tissue matrix ( $\mathrm{p}=0.019$ at 7 days, and $\mathrm{p}=0.009$ at 30 days) and low scores for bone-matrix formation ( $\mathrm{p}=0.043$ at 7 days, $\mathrm{p}=0.005$ at 14 days, and $\mathrm{p}=0.016$ at 30 days). In addition, trabecular connectivity was

Table I. Median scores (range) for each tissue element in accordance with groups and experimental time period.

\begin{tabular}{|c|c|c|c|c|c|c|c|c|c|c|}
\hline \multirow[b]{2}{*}{ Tissue } & \multicolumn{4}{|c|}{ Control group $(n=25)$} & \multicolumn{6}{|c|}{ Experimental group $(n=25)$} \\
\hline & 1d & 3d & $7 d$ & $14 d$ & 30d & 1d & 3d & $7 d$ & 14d & 30d \\
\hline \multirow[t]{2}{*}{ Necrosis } & 0 & 0 & 0 & 0 & 0 & 0 & 0 & 0 & 0 & 0 \\
\hline & $(0-0)$ & $(0-0)$ & $(0-0)$ & $(0-0)$ & $(0-0)$ & $(0-0)$ & $(0-1)$ & $(0-0)$ & $(0-0)$ & $(0-0)$ \\
\hline \multirow[t]{2}{*}{ Clot } & 4 & 2 & 2 & 1 & $\mathbf{0}$ & 4 & 2.5 & 1 & 1 & 1 \\
\hline & $(3-4)$ & $(2-3)$ & $(1-3)$ & $(0-2)$ & $(0-0)$ & $(4-4)$ & $(2-3)$ & $(1-2)$ & $(1-2)$ & $(0-2)$ \\
\hline Inflammatory & 0 & 1 & 1 & $\mathbf{0}$ & 0 & 0 & 1.5 & 1 & 1 & 0 \\
\hline infiltration & $(0-0)$ & $(1-1)$ & $(1-2)$ & $(0-1)$ & $(0-0)$ & $(0-0)$ & $(1-2)$ & $(0-2)$ & $(0-1)$ & $(0-0)$ \\
\hline \multirow[t]{2}{*}{ Edema } & 0 & 1 & 1 & 1 & 0 & 0 & $\mathbf{0}$ & 0 & 1 & 0 \\
\hline & $(0-0)$ & $(1-1)$ & $(0-2)$ & $(0-2)$ & $(0-0)$ & $(0-0)$ & $(0-1)$ & $(0-1)$ & $(0-1)$ & $(0-1)$ \\
\hline Connective & 0 & 1 & 2 & 3 & 2 & 0 & 1 & 4 & 2 & 4 \\
\hline tissue matrix & $(0-0)$ & $(1-1)$ & $(2-3)$ & $(2-3)$ & $(2-3)$ & $(0-0)$ & $(1-2)$ & $(2-4)$ & $(2-4)$ & $(2-4)$ \\
\hline \multirow[t]{2}{*}{ Angiogenesis } & 0 & 1 & 1 & 1 & 2 & 0 & 1 & 3 & 1 & 3 \\
\hline & $(0-0)$ & $(1-2)$ & (1-3) & $(1-2)$ & $(2-2)$ & $(0-0)$ & $(0-2)$ & $(2-4)$ & $(1-2)$ & $(1-3)$ \\
\hline Bone matrix & 0 & 0 & 2 & 3.5 & 4 & 0 & 0 & 1 & 1 & 2 \\
\hline formation & $(0-0)$ & $(0-0)$ & (1-3) & $(3-4)$ & $(4-4)$ & $(0-0)$ & $(0-0)$ & $(0-2)$ & (1-4) & $(1-4)$ \\
\hline Trabeculae & 0 & 0 & 1 & 3 & 4 & 0 & 0 & $\mathbf{0}$ & 1 & 2 \\
\hline connectivity & $(0-0)$ & $(0-0)$ & $(0-2)$ & $(2-4)$ & $(4-4)$ & $(0-0)$ & $(0-0)$ & $(0-0)$ & $(0-3)$ & $(0-4)$ \\
\hline
\end{tabular}

Scores: 0 . Absent; 1 . Tissue element presenting up to $25 \%$ of the alveolus area; 2 . Tissue element present in $50 \%$ of the alveolus; 3 . Tissue element present in $75 \%$ of the alveolus; 4. Tissue element present in more than $75 \%$ of the alveolus.

Scores in red were significantly different when the two groups were compared for each variable and experimental time period (MannWhitney test, significant when $\mathrm{p}<0.05$, see Results text. 
significantly more pronounced in the control group from days 7 to 30 ( $\mathrm{p}=0.016$ at 7 days, $\mathrm{p}=0.003$ at 14 days, and $\mathrm{p}=0.016$ at 30 days).

Fig. 1 illustrates representative slices used for histological characterization in each group from day 1 to day 30. At day 1, the control and PRP groups exhibited remnants of the periodontal ligament inserted into the alveolar-wall bone. Large blood vessels showing hyperaemia were present in the periodontal ligament. No sign of inflammatory infiltrate, necrosis or disruption of the alveolus wall was observed. The interior of the socket was completely filled with an organized clot that consisted mainly of erythrocytes, platelets, and fibrin. Histological aspects of these clots were very similar between the groups (Figs. 1A and 1B).

At 3 days, large numbers of macrophages were observed in the control group in the periphery of the clot, which exhibited partial resorption. Moderate inflammatory infiltrates and angiogenesis were present in the remnants of the periodontal ligament, forming mature granulation tissue (Fig. 1C). In the PRP group, the clot exhibited a substantial fibrin matrix. Macrophages were not observed near the clot, but lymphocyte infiltration was noted in a majority of the specimens (Fig. 1D). Granulation tissue was present in the periphery of the clot.

At 7 days, the clot was being replaced in the control group by a dense collagen matrix with numerous large blood vessels. Bone-matrix deposition was evident, together with intense osteoblastic activity (Fig. 1E). In PRP group, the clot was present in isolated areas of the alveolus; a collagen matrix with intense cellularity and a large quantity of blood vessels was the predominant finding. Bone-matrix deposition was not intense, by contrast with the control group (Fig. $1 \mathrm{~F})$.

At 14 days, in the control group, the clot occupied a low extension of the alveolus. Dense connective tissue filled the alveolar space, and a large quantity of bone matrix was present and extended from the walls to the centre of alveolus. Bone trabeculae exhibited intense connectivity (Fig. 1G). In the PRP group, the clot occupied a large extension in the alveolus and exhibited a high concentration of platelets. Bone matrix was observed in a lower extension than in the control group (Fig. 1H).

Finally, at 30 days, all individual animals in the control group exhibited intense trabecular bone formation in the alveolar area. This trabecular bone was characterized by obvious connectivity and complete fusion with the alveolar wall. The bone marrow consisted of delicate connective tissue that formed a reticular pattern and a small number of fibres. Clot remnants were not present (Fig. 1I). In the PRP group, bone deposition was less intense, and the bone marrow consisted of fibrous connective tissue, together with many blood vessels (Fig. 1J). Clot remnants were present in some cases.

Histomorphometric analysis. The mean percentage of new bone formation in relation to the alveolar area is presented in Fig. 2. At days 7 and 14, this mean percentage was significantly greater in the control group than in PRP group. At day 30, the control group also exhibited the largest mean area, but the mean area was not significantly different between the PRP group and the control group. In both groups, the alveolus was not completely filled with bone tissue at the end of the experiment. Notably, in the control group, the bone-tissue percentages obtained for day 30 were similar to those observed at day 14 (Friedman test, $\mathrm{p}=0.0025$; day 7 compared with days 14 and $30, \mathrm{p}<0.05$; day 14 compared with day $30, p>0.050)$. This result may indicate that the maximum bone tissue-deposition rate was present on day 14 and did not exceed $73 \pm 25 \%$ in this group. However, in the PRP group, the bone-tissue percentage continued to grow from days 7 to 30, with a significant increase in the bonetissue percentage observed on day $30(61 \pm 10 \%$, Friedman test, $\mathrm{p}=0.0001$; day 7 compared with day $14, \mathrm{p}<0.05$; day 14 compared with day $30, \mathrm{p}<0.05$ ).

\section{DISCUSSION}

The present study evaluated the effects of PRP on the alveolar repair process using an animal model. Similar results were found in the experimental and control groups at the end of the experiment, with new bone filling nearly the entire socket and being difficult to distinguish from the original, mature bone of the alveolar wall. Thus, treatment with PRP was not found to facilitate alveolar wound healing in rats. Another study using premolar extraction sockets in dogs similarly demonstrated that treatment with PRP did not result in sufficient alveolar bone retention (Hatakeyama et al., 2014). In the present study, even with complete closure of the sockets with sutures, the results were no better. The findings of other experimental studies in other structures have also questioned its efficacy; for example, in studies of mandibular defects in a dog model (Gerard et al.), criticalsize defects in the forehead in a goat model (Mooren et al.), or even calvarial defects in a rabbit model (Oliveira Filho et $a l$.), treatment with PRP did not enhance healing of autogenous bone grafts. A histologic evaluation of osseous regeneration following combination therapy with PRP and Bio-Oss in an experimental study showed that the use of PRP alone or in combination with this bovine bone derivate 

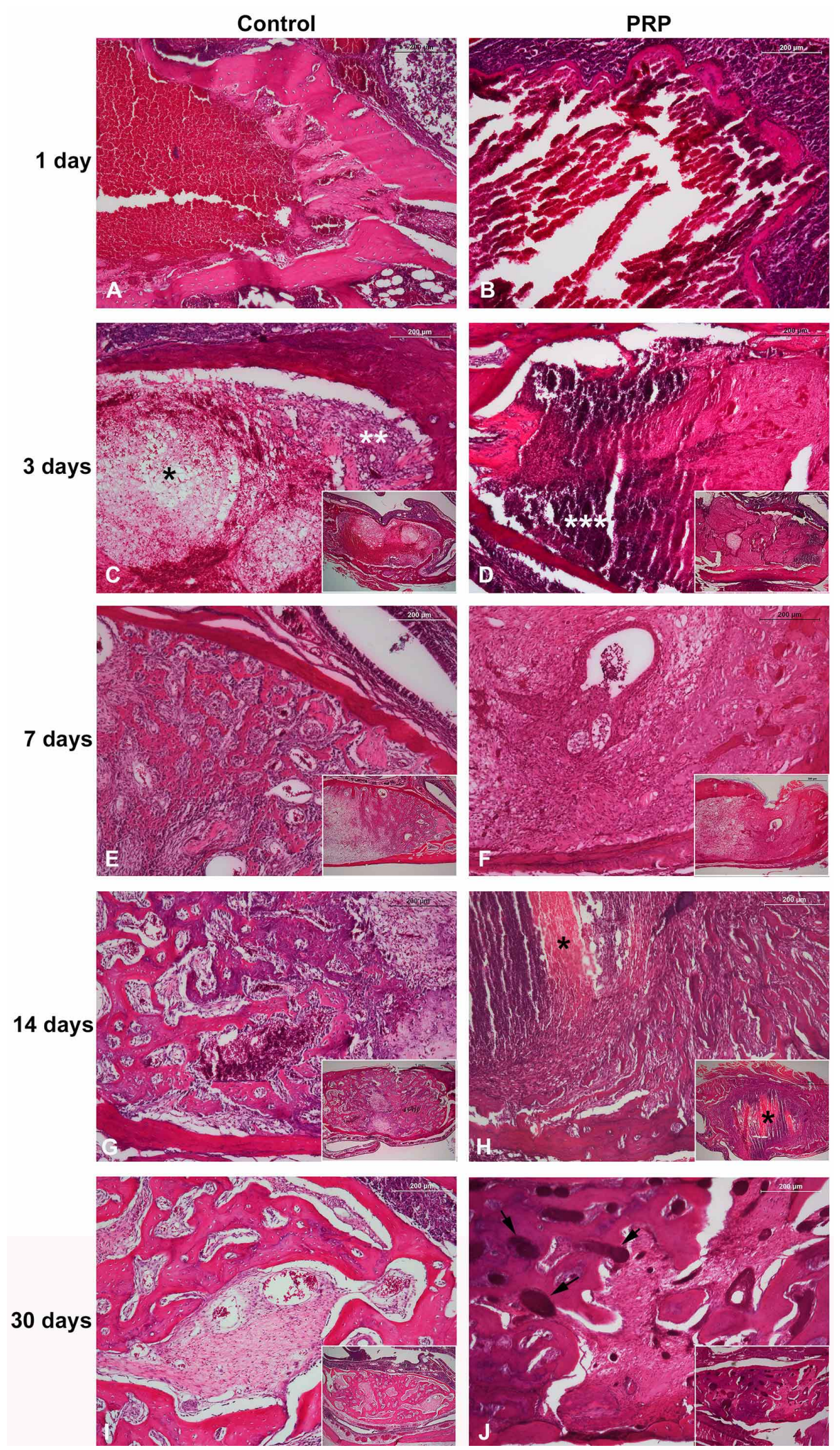

Fig. 1. Representative histological sections (middle third) for the control and PRP (platelet-rich plasma) groups for each experimental time point (haematoxylin and eosin stain; large pictures: original magnification, 100×; bar, $200 \mu \mathrm{m}$; small pictures: original magnification, $25 \times$ or $50 \times$; bar, $500 \mu \mathrm{m}$ or $1000 \mu \mathrm{m})$. A and B (1 day): In the control and PRP groups, the alveolar was filled with a blood clot rich in fibrin and platelets. There was no sign of inflammation or necrosis. C (3 days): In the control group, partial resorption of the clot by macrophages (*) and granulation tissue formation $(* *)$ in the clot periphery were observed. D (3 days): In the PRP group, inflammatory infiltrates $(* * *)$ and massive deposition of fibrin in the clot were observed. In the two groups, the clot occupied the entire alveolar space without bone-matrix formation (small pictures). E (7 days): In the control group, initial deposition of bone matrix and intense osteoblastic activity were observed and substituted for granulation tissue. Few clot remnants were present in the alveolar space (small picture). F (7 days): In the PRP group, little deposition of bone matrix was observed, and fibrous connective tissue was present in the alveolar space. Large vascular spaces were frequently observed. Intense clot resorption was observed in the alveolar space (small picture). G (14 days): In the control group, the alveolar space was almost filled with immature bone tissue, which exhibited high trabecular connectivity (large and small pictures). H (14 days): In the PRP group, the alveolar space exhibited fibrous connective tissue, bone tissue matrix in the periphery and clot remnants in the central region (*). I and $\mathrm{J}$ (30 days): Both the control and PRP groups exhibited bone trabeculae occupying the alveolar space (small picture). Connective tissue in the bone marrow of the PRP group had more collagen fibres than that in the control group. In this representative image, clot remnants were present within trabecular bone in the PRP group (arrows) 


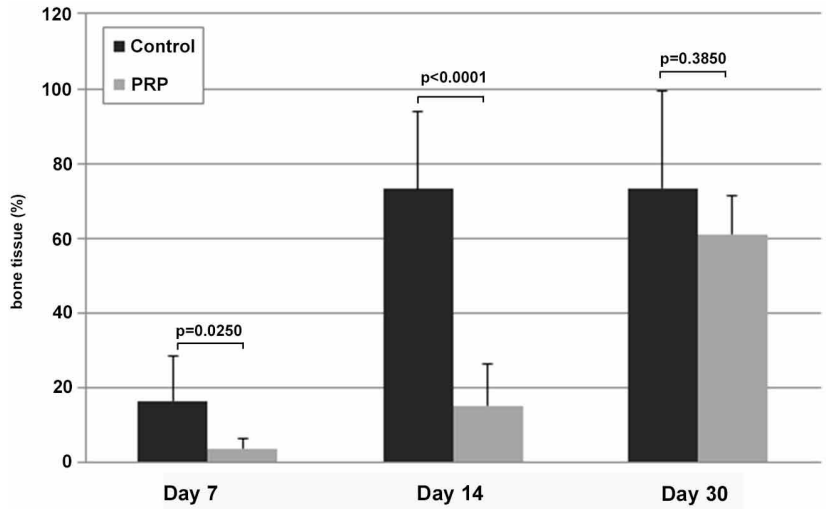

Fig. 2. Means ( \pm standard deviations) of bone-tissue percentages in the alveolar space are presented for each group and experimental time point.

did not appear to enhance osseous regeneration (DeNicolo et al., 2015). Also, a systematic review and meta-analysis indicated no influence of PRP with bone graft on bone formation and implant survival in maxillary sinus augmentation (Lemos et al., 2016). The possibility that early positive effects of PRP-derived growth factors occur before being naturally degraded suggests that their effects on osseous regeneration were short lived or not significant (DeNicolo et al.).

Experimental models of dental extraction, especially of the maxillary incisor or mandibular molar in rats, have contributed to a greater knowledge of alveolar wound healing (Yugoshi et al., 2002; Elsubeihi \& Heersche, 2004; Hatakeyama et al.) and of factors that influence this process. In the present study, a method involving a single centrifugation step and the addition of calcium chloride was used to obtain PRP. A portion of the red blood cells found at the upper portion of the tube were included because of the presence of younger platelets among these cells (Marx). Nylon was used for the sutures, as this suture material achieves better repair results.

Initially, the socket was filled with a blood clot, and remnants of the periodontal ligament were present. In the experimental group, the clot was already organized, possibly due to the use of PRP. On day 7, newly formed bone was found, together with osteoblastic activity, along the walls of the socket (Yugoshi et al.; Elsubeihi \& Heersche), and connective tissue filled the remainder of the socket. It is worth noting that the semiquantitative analysis in this study showed a tendency toward increased angiogenesis and the deposition of dense connective tissue with the use of PRP. On day 14, new bone formation, together with osteoblastic activity, was observed in both groups. However, at this time point, bone was present in the socket to a greater extent in the control group; this difference between the groups was highly significant, indicating a trend toward the formation of a fibrous scar in the alveolar space in the PRP group in comparison with the control group, with a few instances of intense bone deposition in the alveolus in comparison with the control group, as well. A study demonstrated that the maximum mineral deposition rate occurs at two weeks (Hatakeyama et al.).

At the end of the experimental period, in both groups, new bone filled the socket and was difficult to distinguish from the original, mature bone of the alveolar wall. In the experimental group, the bone marrow that was present contained fibrous connective tissue, together with many blood vessels and macrophages; this finding suggests a tendency to form a scar inside the alveolus, although trabecular bone was also present. It is probable that the number of individual animals that were studied was insufficient to show statistically significant differences between the groups in this semiquantitative analysis at this experimental time point. In rats, alveolar repair has been reported to be complete after 21 days; however, bone formation continues to occur beyond this period (Elsubeihi $\&$ Heersche). Bone mineral density of the edentulous mandible following extraction of molars and the incisor of rats unilaterally increases up to 56 days, but total bone volume increases up to 112 days post-extraction (Elsubeihi \& Heersche). Our study was extended by four weeks, a period considered appropriate in man, also considering the rat metabolism with faster responses. However, it is important to evaluate alveolar repair for more than one month in further studies, in special relative to bone mineral density.

In the present study, PRP did not enhance alveolar wound healing in rats. This finding is in agreement with data from experimental studies that have questioned the utility of PRP in bone repair (Gerard et al.; Mooren et al.; Oliveira Filho et al.). It has been demonstrated that PRP can stimulate the proliferation of bone marrow stromal cells in vitro, while reducing alkaline phosphatase activity and calcium deposition, indicating that PRP inhibits osteogenic differentiation (Arpornmaeklong et al., 2004). Thus, PRP should not be considered a substitute for either platelet-poor plasma or bone morphogenetic protein-2 (Arpornmaeklong et al.; Hatakeyama et al.). Also, our findings that the PRP did not promote favorable effects on bone healing could be related to the method of production. It has been described that to be functional PRP should be achieved 4- to 5-fold Increase over baseline platelet numbers (Marx). Authors have reported that red blood cells will interfere in the overall platelet concentration independently of $\mathrm{G}$ force and the time used in the centrifugation (Geaney et al., 2011), and a doublecentrifugation protocol results in higher platelet 
concentrations (Nagata et al., 2010; Geaney et al.; Lemos et $a l$.$) . Thus, further studies are needed with this approach$ relative to the alveolar wound healing.

It has been stated that many of the studies reporting a positive effect of PRP do not meet standard recommendations for study quality (Plachokova et al.). Nevertheless, it has been suggested that PRP is a biologic adhesive that can hold graft particles together, making it easier to manipulate them (Gerard et al.). PRP can be used to improve the stability of the graft in the recipient site (DeNicolo et al.; Lemos et al.). It is important to remember that PRP is a non-toxic, autologous product that poses no risk of transmitting infectious diseases. A systematic review of the effects of PRP concluded that it is of minimal benefit in sinus elevation but that it is of clear benefit in the treatment of periodontal defects (Plachokova et al.). The effect of PRP in alveolar distraction osteogenesis was evaluated and its addition had a protective effect on the mucous membrane around the distractor, which decreased the potential for complications (Menezes et al., 2016). These favorable effects in soft tissue repair have been attributed to antimicrobial properties of PRP. It has been demonstrated in vitro that PRP presents antimicrobial activity against gram positive bacteria isolated from oral cavity (Drago et al., 2014), which may lead to practical implications of its application.

\section{CONCLUSIONS}

The present experimental study evaluated the effects of PRP on alveolar wound healing in rats using histological and digital histometric methods. PRP did not enhance alveolar socket repair and led to low rates of bone-tissue formation during intermediate phases of bone repair; these findings indicate that this method had no efficacy after experimental dental extraction.

\section{ACKNOWLEDGMENTS}

The authors are grateful to Prof. Nivea Lopes de Souza of the School of Veterinary Medicine and Animal Science of the University of São Paulo for her technical assistance.

YAMAMOTO, M. K. ; NOVELLI, M. D.; CORRÊA, L.; DE SOUSA, S. C. M. \& LUZ, J. G. C. Evaluación del efecto del plasma rico en plaquetas en la cicatrización de heridas alveolares en ratas. Int. J. Morphol., 35(1):251-258, 2017.

RESUMEN: Las opiniones sobre la utilidad clínica del plasma rico en plaquetas (PRP) varían, ya que un gran número de estudios experimentales han cuestionado su eficacia. El propósito de este estudio fue evaluar los efectos del PRP sobre la cicatrización experimental de heridas alveolares en ratas. Cincuenta ratas Wistar adultas fueron divididas en grupos control y PRP, y fueron sometidas a extracción del incisivo maxilar derecho. En el grupo de PRP, la sangre se recogió por punción cardiaca, y el alvéolo se llenó con un gel de PRP. Los animales se sacrificaron después de 1, 3, 7, 14 y 30 días. Se realizaron análisis histológicos e histomorfométricos en cada momento experimental. El análisis histológico semicuantitativo mostró que el grupo de PRP exhibió significativamente más deposición de matriz de colágeno y menos formación de matriz ósea en el receptáculo que el grupo control de 7 a 30 días. Los análisis histomorfométricos mostraron que el grupo PRP también exhibió áreas de tejido óseo inferiores al grupo control a 7 ( $\mathrm{p}=0,0250)$ y 14 días ( $\mathrm{p}<0,0001$ ), pero a los 30 días no se observó diferencia significativa entre los grupos. En el presente estudio, el PRP no mejoró la cicatrización de las heridas alveolares, y las ratas tratadas con PRP mostraron bajas tasas de deposición ósea durante las fases intermedias de la reparación de los receptáculos alveolares.

PALABRAS CLAVE: Alvéolo del diente; Cicatrización de la herida; Plasma rico en plaquetas; Experimentación animal.

\section{REFERENCES}

Alissa, R.; Esposito, M.; Horner, K. \& Oliver, R. The influence of plateletrich plasma on the healing of extraction sockets: an explorative randomised clinical trial. Eur. J. Oral Implantol., 3(2):121-34, 2010.

Arpornmaeklong, P.; Kochel, M.; Depprich, R.; Kübler, N. R. \& Würzler, K. K. Influence of platelet-rich plasma (PRP) on osteogenic differentiation of rat bone marrow stromal cells. An in vitro study. Int. J. Oral Maxillofac. Surg., 33(1):60-70, 2004.

DeNicolo, P. J.; Guyton, M. K.; Cuenin, M. F.; Hokett, S. D.; Sharawy, M.; Borke, J. \& McPherson, J. C. $3^{\text {rd }}$. Histologic evaluation of osseous regeneration following combination therapy with platelet-rich plasma and bio-oss in a rat calvarial critical-size defect model. J. Oral Implantol., 41(5):543-9, 2015.
Devlin, H. \& Sloan, P. Early bone healing events in the human extraction socket. Int. J. Oral Maxillofac. Surg., 31(6):641-5, 2002.

Drago, L.; Bortolin, M.; Vassena, C.; Romanò, C. L.; Taschieri, S. \& Del Fabbro, M. Plasma components and platelet activation are essential for the antimicrobial properties of autologous platelet-rich plasma: An in vitro study. PLoS One, 9(9):e107813, 2014.

Elsubeihi, E. S. \& Heersche, J. N. Quantitative assessment of post-extraction healing and alveolar ridge remodelling of the mandible in female rats. Arch. Oral Biol., 49(5):401-12, 2004.

Geaney, L. E.; Arciero, R. A.; DeBerardino, T. M. \& Mazzocca, A. D. The effects of platelet-rich plasma on tendon and ligament: Basic science and clinical application. Oper. Tech. Sports Med., 19(3):160-4, 2011. 
Gerard, D.; Carlson, E. R.; Gotcher, J. E. \& Jacobs, M. Effects of plateletrich plasma on the healing of autologous bone grafted mandibular defects in dogs. J. Oral Maxillofac. Surg., 64(3):443-51, 2006.

Gürbüzer, B.; Pikdöken, L.; Urhan, M.; Süer, B. T. \& Narin, Y. Scintigraphic evaluation of early osteoblastic activity in extraction sockets treated with platelet-rich plasma. J. Oral Maxillofac. Surg., 66(12):2454-60, 2008.

Hatakeyama, I.; Murukawa, E.; Takahashi, Y. \& Omura, K. effects of platelet-poor plasma, platelet-rich plasma, and platelet-rich fibrin on healing of extraction sockets with buccal dehiscence in dogs. Tissue Eng. Part A, 20(3-4):874-82, 2014.

Kutkut, A.; Andreana, S.; Kim, H. L. \& Monaco, E. Jr. Extraction socket preservation graft before implant placement with calcium sulfate hemihydrate and platelet-rich plasma: a clinical and histomorphometric study in humans. J. Periodontol., 83(4):401-9, 2012.

Lemos, C. A.; Mello, C. C.; dos Santos, D. M.; Verri, F. R.; Goiato, M. C. \& Pellizzer, E. P. Effects of platelet-rich plasma in association with bone grafts in maxillary sinus augmentation: a systematic review and meta-analysis. Int. J. Oral Maxillofac. Surg., 45(5):517-25, 2016.

Marx, R. E. PlatelPlatelet-rich plasma: evidence to support its use. J. Oral Maxillofac. Surg., 62(4):489-96, 2004.

Menezes, D. J.; Shibli, J. A.; Gehrke, S. A.; Beder, A. M. \& Sendyk, W. R. Effect of platelet-rich plasma in alveolar distraction osteogenesis: a controlled clinical trial. Br. J. Oral Maxillofac. Surg., 54(1):83-7, 2016.

Mooren, R. E.; Merkx, M. A.; Bronkhorst, E. M.; Jansen, J. A. \& Stoelinga, P. J. The effect of platelet-rich plasma on early and late bone healing: an experimental study in goats. Int. J. Oral Maxillofac. Surg., 36(7):62631, 2007.

Nagata, M. J.; Messora, M. R.; Furlaneto, F. A.; Fucini, S. E.; Bosco, A. F.; Garcia, V. G.; Deliberador, T. M. \& de Melo, L. G. Effectiveness of Two methods for preparation of autologous platelet-rich plasma: An experimental study in rabbits. Eur. J. Dent., 4(4):395-402, 2010.

Oliveira Filho, M. A.; Nassif, P. A.; Malafaia, O.; Ribas Filho, J. M.; Ribas, C. A.; Camacho, A. C.; Stieven Filho, E. \& Giovanini, A. F. Effects of a highly concentrated platelet-rich plasma on the bone repair using noncritical defects in the calvaria of rabbits. Acta Cir. Bras., 25(1):28-33, 2010.

Oyama, T.; Nishimoto, S.; Tsugawa, T. \& Shimizu, F. Efficacy of plateletrich plasma in alveolar bone grafting. J. Oral Maxillofac. Surg., 62(5):555-8, 2004.

Plachokova, A. S.; Nikolidakis, D.; Mulder, J.; Jansen, J. A. \& Creugers, N. H. Effect of platelet-rich plasma on bone regeneration in dentistry: a systematic review. Clin. Oral Implants Res., 19(6):539-45, 2008.

Sammartino, G.; Tia, M.; Gentile, E.; Marenzi, G. \& Claudio, P. P. Plateletrich plasma and resorbable membrane for prevention of periodontal defects after deeply impacted lower third molar extraction. J. Oral Maxillofac. Surg., 67(11):2369-73, 2009.

Sánchez, A. R.; Sheridan, P. J. \& Kupp, L. I. Is platelet-rich plasma the perfect enhancement factor? A current review. Int. J. Oral Maxillofac. Implants, 18(1):93-103, 2003.

Steigmann, M. \& Garg, A. K. A comparative study of bilateral sinus lifts performed with platelet-rich plasma alone versus alloplastic graft material reconstituted with blood. Implant Dent., 14(3):261-6, 2005.

Weibrich, G.; Kleis, W. K.; Hafner, G. \& Hitzler, W. E. Growth factor levels in platelet-rich plasma and correlations with donor age, sex, and platelet count. J. Craniomaxillofac. Surg., 30(2):97-102, 2002.

Wiltfang, J.; Schlegel, K. A.; Schultze-Mosgau, S.; Nkenke, E.; Zimmermann, R. \& Kessler, P. Sinus floor augmentation with betatricalciumphosphate (beta-TCP): does platelet-rich plasma promote its osseous integration and degradation? Clin. Oral Implants Res., 14(2):213-8, 2003.

Yugoshi, L. I.; Sala, M. A.; Brentegani, L. G. \& Carvalho, T. L. L. Histometric study of socket healing after tooth extraction in rats treated with diclofenac. Braz. Dent. J., 13(2):92-6, 2002.

\author{
Corresponding author: \\ João Gualberto C. Luz \\ Rua Duarte de Azevedo, 284 - cj. 22 \\ 02036-021 \\ São Paulo SP \\ BRAZIL
}

\section{E-mail:jgcluz@usp.br}

Received: 18-09-2016

Accepted: 22-12-2016 